2020

\title{
The Complex Challenges of Protecting Consumers
}

Deniz Atik

University of Texas Rio Grande Valley

Nikhilesh Dholakia

University of Rhode Island

Follow this and additional works at: https://digitalcommons.uri.edu/mgdr

Part of the Anthropology Commons, Economics Commons, Marketing Commons, Other Business Commons, and the Sociology Commons

\section{Recommended Citation}

Atik, Deniz and Dholakia, Nikhilesh (2020) "The Complex Challenges of Protecting Consumers," Markets, Globalization \& Development Review: Vol. 5: No. 2, Article 1.

DOI: 10.23860/MGDR-2020-05-02-01

Available at: https://digitalcommons.uri.edu/mgdr/vol5/iss2/1

This Editorial is brought to you for free and open access by DigitalCommons@URI. It has been accepted for inclusion in Markets, Globalization \& Development Review by an authorized editor of DigitalCommons@URI. For more information, please contact digitalcommons-group@uri.edu. 


\section{The Complex Challenges of Protecting Consumers}

\section{Markets, Globalization \& Development Review}
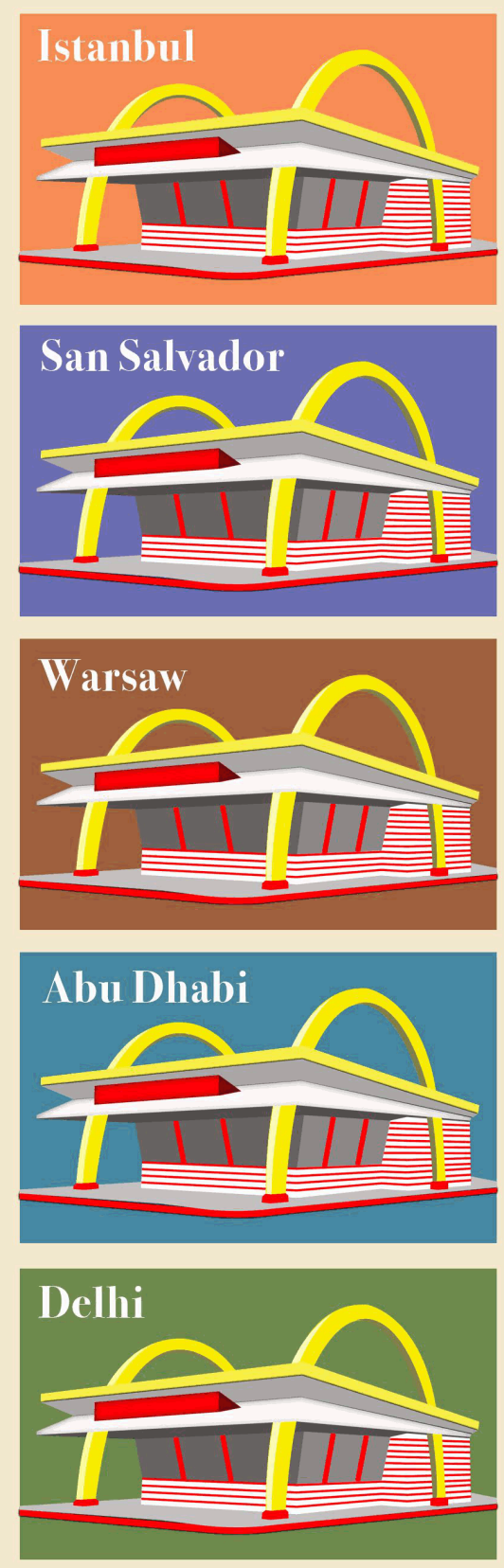
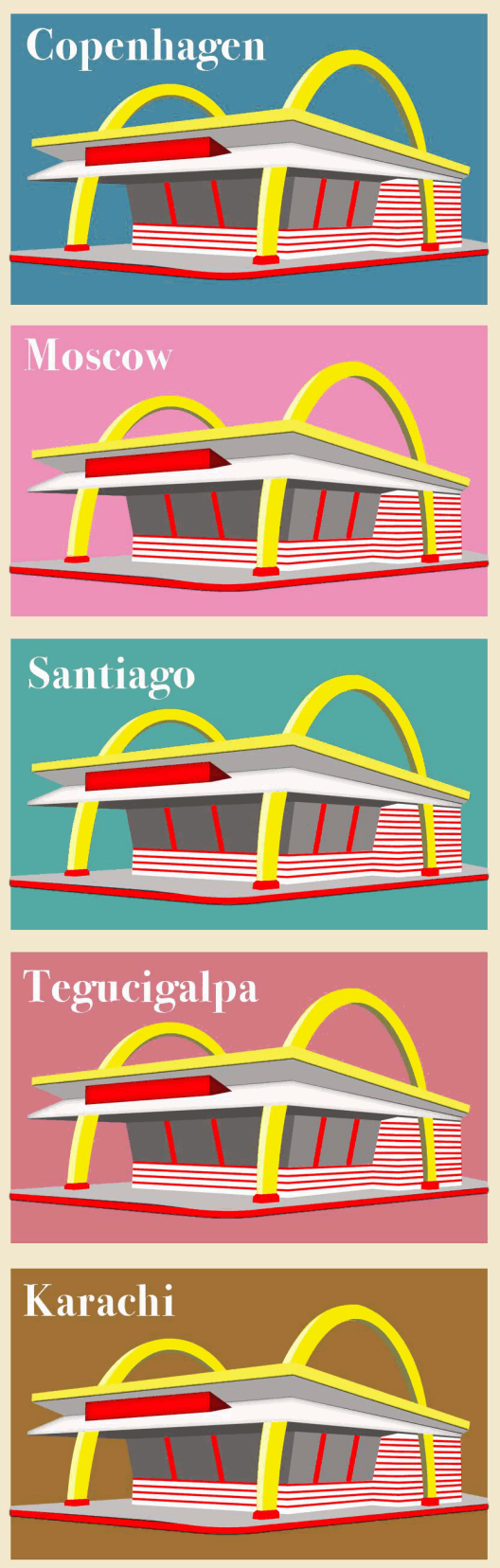
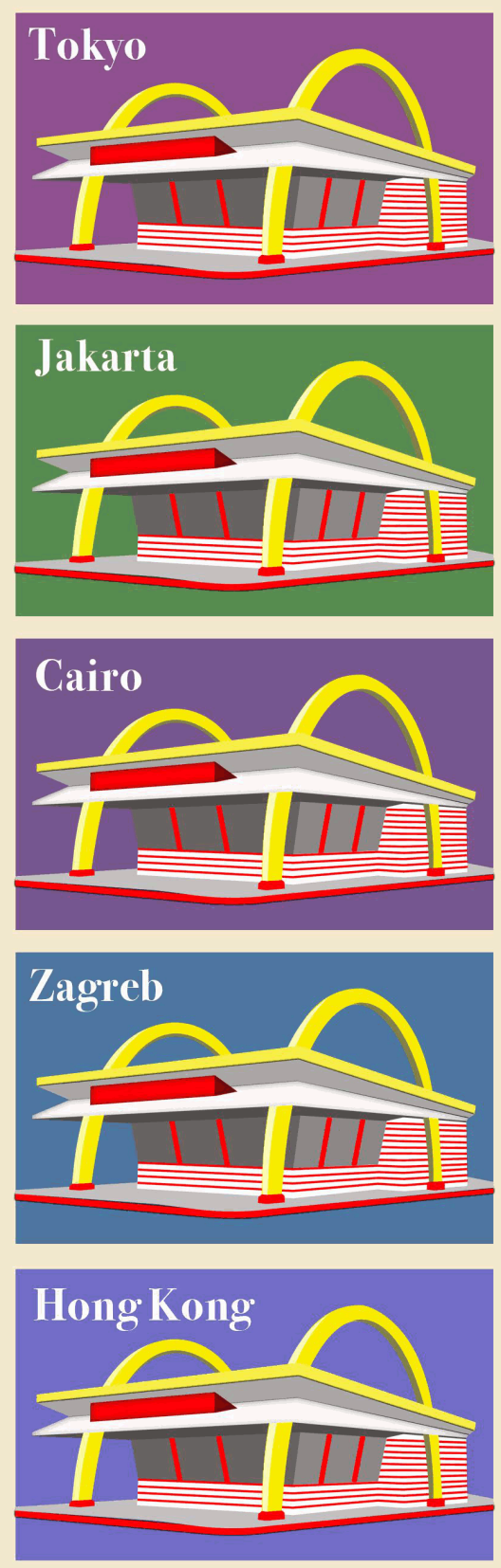

This editorial is available in Markets, Globalization \& Development Review: https://digitalcommons.uri.edu/mgdr/ vol5/iss $2 / 1$ 


\section{The Complex Challenges of Protecting Consumers}

\section{Introduction}

This second issue of Volume 5 of MGDR touches upon some of the pressing challenges consumers face. Some of these challenges arise from less-than-transparent marketing organizations and marketing practices, such as the obstacles created for consumers by the sugar or meat industries. New technologies, such as Artificial Intelligence (AI), also spawn new ethical dilemmas and challenges for consumers and society - and unforeseeable and unimaginable technologies such as Artificial General Intelligence (AGI) can compound these ethical challenges. This issue also explores the challenges with building city identities, racial diversity challenges in both corporate and social life, and the logistics and infrastructure challenges that most developing nations (as well as some advanced ones, such as the United States) face.

\section{Articles in this Issue}

Employing multiple disciplinary lenses, the first article in this issue of MGDR discusses the effects of high sugar consumption on human health and the role of profit maximizing sugar corporations obscuring some of these effects. According to the article author Ngo (2020), the problem already starts with the lack of consistent regulation, with mystifying nutrition labels and confusing sugar terminology. Sugar is tastefully addictive to consumers - it is an essential nutrient but its taste effects are addictive. Sugar is very profitable for corporations that do everything in their power for its promotion. Healthier sounding names such as honey, fruit juice or agave nectar - all essentially forms of sugar - are employed in labels to lull consumers into thinking they are consuming things that are healthier than sugar. Ngo further unveils the obstacles created by marketing sugar to children and the influence of sugar industry on policymakers and policy influencers. Finally, she provides recommendations for reducing sugar consumption and points to the need to investigate further, using a range of disciplines, as to how consumers feel or think about sugar and the role it plays in consumers' lives.

The second article in this issue is about the moral and ethical aspects of artificial intelligence ( $\mathrm{Al}$ ) technology. $\mathrm{Al}$ is already a part of consumers' daily lives through the technology used in mobile phones and smart devices such as Amazon's Alexa, Microsoft's Cortana, Apple's Siri, Global Positioning Systems (GPS); and these Al-based 
systems provide verbal information in highly credible ways. The critical question Murray (2020) raises is whether such technology is leading consumers in the direction they want to go in, or away from it. More specifically, the author argues that "Al may be providing information based on the created ethical framework of the provider seen in their business ethics and corporate handbooks, which may be different from the consumers' moral values" (p.4). Murray (2020) debates the issues thoroughly - using many real-life examples - the potential problems of creating a technology that will make smart decisions in its interactions with humans, and suggests potential solutions that would keep consumer interests in focus, along with corporate and government aims.

In the third article, Godefroit-winkel et al. (2020) investigate how consumers build city identities through the interplay between city attachment, consumption, and urban spaces in the context of Casablanca, Morocco. Through a qualitative inquiry, the authors explore consumer-residents' feelings and thoughts about Casablanca's infrastructure, leisure activities, and features. The inquiry leads them to identify five city identities: city of escape, busy isolating city, clustering city, small city, and dark city. Interestingly, the authors find that time of consumption is an important factor; indeed, a single resident can build several of these identities depending on the time of the day. In addition, positive and negative emotions can both intermingle in building city attachment, and consumer-residents can develop strong forms of attachment to cities, despite their negative characteristics. The article's authors further suggest that it would be fruitful to examine if city identities and consumer residents' identities influence each other. Since mega-urban conglomerations are in the projected future our planet, at MGDR we hope to receive not only studies such as this one but also reviews and commentaries on works such as 'Maximum City' by Suketu Mehta (2009).

\section{Reviews in this Issue}

The first book review in this issue of MGDR is Gentry's (2020) analysis of Some of my best friends are black: The strange story of integration in America (2012) by Tanner Colby. Gentry argues that although the book is not recent, it became even more relevant with the 'Black Lives Matter' (BLM) movement in the United States in 2020. Gentry provides an overview of the book that exposes the challenges of racial integration in the school system of Birmingham, Alabama, the actions of housing developers in Kansas City, Missouri that increased black people's vulnerability, the white dominance in advertising industry, and the challenges associated with creating a racially united church. Gentry states that "[g]reater understanding of those who are different from the mainstream in power is clearly needed for most of us. This book can be 
a stepping stone in meeting that need" (p.4).

The second book review in this issue reveals a versatile source for MGDR readers who want to understand better China's logistics networks, which are among the key success factors in China's astonishing economic growth, according to the review author Lu (2020). Contemporary Logistics in China: An Introduction is written by Binglian Liu, Shao-ju Lee, Zhilun Jiao, and Ling Wang (2011) - a group of researchers and experts who are affiliated with Modern Logistics Research Center, Nankai University, in Tianjin, China. Lu recommends this book and "the whole series of 'Contemporary Logistics in China' publications for the systematic description of the astounding growth of China's logistics sector in the 21st century. With inside accounts of China's logistics transformation and development, the series offers valuable lessons for both academicians and practitioners" (p.1). According to $\mathrm{Lu}$, the book has a special value because it discusses the logistics industry's response to the global financial crisis of 2008 besides revealing a detailed analysis of the industry at that time. Additionally, the reviewer provides insights not only about this particular book, but also about the whole book-series that followed this particular book. The series of subsequent books contain further information about emerging topics such as service innovation, online shopping logistics, and internationalization of Chinese logistics enterprises as well as cross-border e-commerce logistics.

Finally, the media review in this issue of MGDR is about Okja, a heartbreaking movie, directed by Bong Joon Ho, produced by Netflix in 2017. This is the story Okja, which is a cute pig-like animal, a sweet little Korean girl who took care of Okja, and a fierce profit-maximizing corporation - that poses as a protector of the environment and a fighter against global hunger - that is after Okja's meat. The film review author Uzuner (2020) elaborates the dramatic story of Okja in length, and offers commentaries in terms of mediatization and globalization processes. She particularly draws attention to the relationship between the East and the West as Okja travels from the pristine setting of rural Korea to Seoul and then on to New York. She considers the movie as a critique of capitalism that exposes the cruel dynamics in the supply chain of meat industry from mass production to mass consumption.

\section{Concluding Observations}

One of our aims at MGDR is to continue to refocus on the three defining and anchoring terms in the journal's title: markets, globalization and development (Fırat 2016). This often takes the articles and reviews into directions that do not fit neatly into publishing categories that are familiar to readers of business, marketing, or even social science journals. Of course, we cover issues relevant to business, markets and consumers; but also delve into topics that range from practical to 
technical to philosophical aspects of social, economic and political processes. We also strive to offer perspectives that often diverge from the western one, though we do of course provide western viewpoints also. For example, in earlier MGDR issues, we have examined the supply chain and logistical (and manufacturing) issues relating to China, but from the perspective of scholars based in Europe (Yu and Yalcin 2017). In this issue, the review of the logistics and infrastructure developments in China are by a scholar who, though not currently based in China, is intimately familiar not just with the government and industry settings of China but also well acquainted with the academic research settings of China (Lu 2020). Similarly, in the diverse and global spirit that imbues the contributions in MGDR, the city-identity paper is focused on a North African city and represents collaborative effort of European and North African scholars (Godefroit-winkel et al. 2020). The movie review of 'Okja' - of course, the film itself is global, spanning locations as different as Chile, Korea and the U.S. - represents an intersectional scholarly viewpoint that tries to present western and non-western perspectives. We hope to continue this tradition and trend at MGDR, and welcome ideas on how to do so in creative, innovative and probing ways. 


\section{References}

Firat, A. Fuat (2016), "The Dynamics of the Local and the Global: Implications for Marketing and Development," Markets, Globalization \& Development Review, 1 (1), Article 4. https://doi.org/10.23860/MGDR-2016-01-01-04

Gentry, James W. (2020), "Tanner Colby, Some of My Best Friends are Black (2012)," Markets, Globalization \& Development Review, 5 (2), Article 6. https://doi.org/10.23860/MGDR-2020-05-02-06

Godefroit-winkel, Delphine, Marie Schill, Cristina Longo and Martin Chour (2020), "Building City Identities: A Consumer Perspective," Markets, Globalization \& Development Review, 5 (2), Article 4. https://doi.org/10.23860/MGDR-2020-05-02-04

Lu, Qing (2020), "Liu, Lee, Jiao, and Wang, Contemporary Logistics in China: An Introduction (2011)," Markets, Globalization \& Development Review, 5 (2), Article 5. https://doi.org/10.23860/MGDR-2020-05-02-05

Mehta, Suketu (2009), Maximum City: Bombay Lost and Found, New York: Vintage.

Ngo, Ai Nhan (2020), "Hidden Sugar and its Bitter Barriers for the Wellbeing of Consumers," Markets, Globalization \& Development $\begin{array}{llll}\text { Review, } & 5 & (2), & \text { Article }\end{array}$ https://doi.org/10.23860/MGDR-2020-05-02-02

Murray, Ross (2020), "The Perceived Ethics of Artificial Intelligence," Markets, Globalization \& Development Review, 5 (2), Article 3. https://doi.org/10.23860/MGDR-2020-05-02-03

Uzuner, Nagehan (2020), "Bong Joon Ho, Okja (2017): Wounding the Feelings," Markets, Globalization \& Development Review, 5 (2), Article 7. https://doi.org/10.23860/MGDR-2020-05-02-07

Yu, Degan and Mehmet G. Yalcin (2017), "Nassimbeni and Sartor, Sourcing in China (2006)," Markets, Globalization \& Development Review, (2) 4, Article 4. https://doi.org/10.23860/MGDR-2017-02-04-04 